\title{
Advancing Reconnaissance and Valorisation: Map Series of German South West Africa (Namibia), 1892-1918
}

\author{
Imre Josef Demhardt ${ }^{\mathrm{a}}$ * \\ a University of Texas at Arlington, demhardt@uta.edu \\ * Corresponding author
}

Keywords: Namibia, Topography, Map Series

\begin{abstract}
:
Although the Portuguese discovered the shores of south-western Africa as early as 1487, its hostile coastal desert Namib delayed even limited European reconnaissance of the hinterland until late in the eighteenth century. It was not before the second half of the nineteenth century that serious commercial and missionary interest took off. These explorations resulted in route and basic overview maps of a rugged and for the most only sparsely populated region of about one million square kilometres, stretching from the coastal Namib Desert across a central highland to the slopes of the Kalahari basin in the heart of the subcontinent.

The need for more detailed mapping arose with the 'Scramble for Africa', when German merchant Adolf Lüderitz in 1883 bought Angra Pequena, one of only two natural harbours on that coast. Along with subsequent acquisitions between the Orange River in the south and the Kunene River in the north with a substantial hinterland, in April 1884 was declared Schutzgebiet Deutsch-Südwestafrika, the first and soon most important German colony in Africa. After establishing the boundaries (1885 with Portugal, 1890 with United Kingdom) and succeeding in pacifying the indigenous communities, colonial penetration and valorisation only was possible based on topographical knowledge. To facilitate this, official series ranged from small-scale coverage with scattered features for peripheral regions, often based on simple route traverses, to very detailed and triangulation backed large-scale series with significant private supplement series by land and mining concessionaires.
\end{abstract}

This paper discusses the relevant characteristics of nine topographical map series and one atlas, which reflect the scope, achievements and inevitable shortcomings of just a quarter of a century of intense official and private surveying and mapping in German South West Africa:

1892-94 [Francois Sheets], first de facto official series, mostly in 1:300,000

1894-96 Deutscher Kolonial-Atlas by P. Langhans, first completed atlas, 1:2,000,000

1904 Hartmann-Karte of the northern protectorate, first private series, 1:300,000

$1904 \quad$ Kriegskarte by P. Sprigade \& M. Moisel, watershed official series, 1:800,000

1906-08 Deutsch-Südwestafrika, “proto”-version of the official series in medium scale, 1:400,000

1908-12 Krokierblätter Deutsch-Südwestafrika, official series in large scale, 1:100,000

1910 Übersichtskarte des Diamantengebietes, largest scale private series, 1:50,000

1910-12 Deutsch-Südwestafrika, preliminary official series in medium scale, 1:400,000

1913 Karte des Sperrgebiets in the south-western protectorate, private series, 1:100,000

1913-[21?] [Bergrechtskarte] of the central protectorate, last private series, 1:200,000

That scope and output of surveying and topography was only reached again half a century later, after two world wars, a recession and a long-time cartographic indifference by South Africa, custodian of the territory in 1919-90, which also by renewed mapping efforts since the 1970s tried to counter movements towards the ultimate independence of Namibia in 1990. 